\title{
Plasma Glucagon Response to Blood Glucose Fall, Gastrointestinal Hormones and Arginine in Man
}

\author{
Akira Ohneda, Munehiko Sato, Kiyoshi Matsuda, Akira \\ Yanbe, Yoshisuke Maruhama and Shoichi Yamagata \\ The Third Medical Department, * Tohoku University School of \\ Medicine, Sendai
}

\begin{abstract}
Ohneda, A., Sato, M., Matsuda, K., Yanbe, A., Maruhama, Y. and Yama. Gata, S. Plasma Glucagon Response to Blood Glucose Fall, Gastrointestinal Hormones and Arginine in Man. Tohoku J. exp. Med., 1972, 107 (3), 241-251 - The response of plasma glucagon to several stimuli was studied and compared in normal and diabetic subjects. Plasma glucagon was measured by the radioimmunoassay using an anti-glucagon serum, which is relatively specific for pancreatic glucagon. Insulin-induced hypoglycemia caused a marked elevation of plasma glucagon in normal subjects but minimal in diabetic patients. A rapid fall of blood glucose, cataglycemia, induced by the discontinuation of glucose infusion did not show any changes in the level of plasma glucagon. The response of plasma glucagon was not observed after the injection of tetrapeptide of gastrin or secretin, although these hormones induced an increase in the level of plasma insulin. Pancreozymin did not induce any changes in plasma insulin or glucagon in a dosis of one clinical unit per $\mathrm{kg}$ of body weight. The infusion of $30 \mathrm{~g}$ of $\mathrm{L}$-arginine stimulated the secretion of pancreatic glucagon and the plasma level of glucagon was moderately elevated in both normal and diabetic subjects. These results suggest that $L$-arginine infusion is recommended as a tool for the alpha-cell function test of the pancreas in man._- glucagon response; insulin-hypoglycemia; cataglycemia; gastrointestinal hormones; arginine
\end{abstract}

Since the radioimmunoassay for plasma glucagon has been developed, the knowledge on the regulation of the secretion of pancreatic glucagon has been accumulated. At the first, since glucagon was thought to be a hormone of 'glucose need', glucagon secretion due to hypoglycemic states induced by insulin, phloridzine or starvation has been investigated in dogs (Unger et al. 1962, Ohneda et al. 1969). Although Samols et al. (1965) and Lawrence (1966) demonstrated the elevation of circulating glucagon in man following oral glucose load, Unger et al. (1968) reported that the elevated level of glucagon was derived from the gut and that hyperglycemia rather suppressed the secretion of glucagon from the pancreas.

Recently, it was shown that administration of amino acids stimulated the glucagon secretion from the pancreas (Assan et al. 1967, Fajans et al. 1967, Ohneda et al. 1967). Furthermore, it has been suggested that changes in plasma free fatty acids play an important role in the regulation of glucagon secretion (Madison et al. 1968, Unger et al. 1969, Edwards et al. 1969).

Received for publication, November 18, 1971.

* Director: Prof. S. Yamagata. 
It has been demonstrated that among the gastrointestinal hormones, pancreozymin stimulates glucagon secretion as well as insulin from the pancreas in animals (Unger et al. 1967). In 1970, it was reported that tetrapeptide of gastrin (Kaneto et al.) and oxytocin (Kaneto and Kosaka 1970) stimulate the secretion of pancreatic glucagon in dogs.

These results, however, were obtained mostly in the experimental animals and little has been known about the response of plasma glucagon to various stimuli in man. In order to compare the responses to several stimuli in man, the effects of hypoglycemia, a rapid fall of blood glucose, gastrointestinal hormones and Larginine were investigated.

\section{Materials and Methods}

Healthy male students were investigated in this experiment. In addition, diabetic patients admitted to our medical department were studied in the experiment with insulin and L-arginine. All subjects were studied in the morning after overnight fast. After drawing fasting samples, each substance was administered intravenously and blood specimens were obtained at various intervals. Regular insulin (Isuzilin( $)$ purchased from Shimizu Pharmaceutical Co., Shimizu) was injected in a dosis of $0.1 \mathrm{U}$ per kg of body weight to six normal subjects and six diabetic patients. A rapid fall of blood glucose, cataglycemia was induced by the prompt withdrawal of glucose infusion in eight normal subjects. In this study glucose was infused at a rate of $400 \mathrm{mg}$ per minute with a prime dosis of $4 \mathrm{~g}$ of $20 \%$ solution and the infusion of glucose was discontinued 60 min after the start of glucose load. Tetrapeptide of synthetic human gastrin (Gastopsin donated by Nihon Kayaku and Company) was injected in a dosis of $4 \mu \mathrm{g}$ per $\mathrm{kg}$ of body weight to six normal subjects. Porcine secretin and pancreozymin of Boots (gifts of Eisai and Company) were administered in a dosis of each one clinical unit per $\mathrm{kg}$ of body weight to six and five normal subjects, respectively. Ten per cent solution of L-arginine (supplied by Tanabe Pharmaceutical and Company) was infused to eight normal subjects and four diabetic patients for $30 \mathrm{~min}$ in amount of $300 \mathrm{ml}$, respectively.

Blood for glucose measurement was obtained from the ear lobe and blood glucose was determined by glucose oxidase method (Teller, 1956), using Glucostat B. Blood specimens for the assay of hormones were drawn into the heparinized syringes through a plastic needle indwelling into the forearm vein, and chilled in an ice box. Plasma was separated by centrifugation immediately after the completion of the experiment and stored at $-20^{\circ} \mathrm{C}$ until the assay. Plasma insulin was assayed by a modification (Ohneda et al. 1970) of Morgan and Lazarow's method (1962). The radioimmunoassay for glucagon was performed by a modification of the previously described method (Ohneda and Yamagata 1971). In this study, glucagon assay was carried out using an anti-glucagon serum, $30 \mathrm{~K}$, which was donated by Dr. R.H. Unger, Dallas, Texas, U.S.A., because of weak cross-reactivity with gut glucagon-like immunoreactive substance (GLI). In this immunoassay of glucagon, a mixture of $0.2 \mathrm{ml}$ of plasma or standard glucagon, about $20 \mathrm{pg}$ of ${ }^{131} \mathrm{I}$-glucagon with specific radioactivity of 400 to $600 \mathrm{mCi}$ per $\mathrm{mg}, 1000 \mathrm{U}$ of Trasylole and $0.1 \mathrm{ml}$ of antiglucagon serum $(1: 5,000)$ was incubated for $48 \mathrm{hr}$ at $4^{\circ} \mathrm{C}$. The separation of bound labeled glucagon from free one was carried out by the dextran-coated charcoal method of Herbert et al. (1965). In this immunoassay system the minimal detectable dosis of glucagon was $10 \mathrm{pg}$, precision being within $2 \%$ in terms of the rate of bound ${ }^{131}$ I-glucagon. The value of sensitivity was less than $0.2 \mathrm{ng} \mathrm{per} \mathrm{ml}$ in the range of 0 to $2.0 \mathrm{ng} / \mathrm{ml}$ and less than 0.86 $\mathrm{ng} / \mathrm{ml}$ in the range of 2.0 to $8.0 \mathrm{ng} / \mathrm{ml}$ (Ohneda 1971).

In this study, the mean value and standard errors of mean were calculated and the statistical analyses were carried out by t-test. 


\section{Results}

Insulin-induced hypoglycemia: The mean blood glucose fell from the fasting level of $86 \pm 1.5 \mathrm{mg} / 100 \mathrm{ml}$ to the nadir of $40.8 \mathrm{mg} / 100 \mathrm{ml} 15 \mathrm{~min}$ after the insulin injection in normal subjects. Then blood glucose rose and returned to the initial level by $120 \mathrm{~min}$. The mean value of plasma glucagon increased from the baseline of $0.18 \pm 0.06 \mathrm{ng} / \mathrm{ml}$ and reached a peak level of $1.18 \pm 0.40 \mathrm{ng} / \mathrm{ml} 45 \mathrm{~min}$ after the insulin administration. Then the plasma level of glucagon decreased. The plasma levels of glucagon at 30,45,60 and 90 min were significantly elevated as compared with the fasting level. These changes in blood glucose and plasma glucagon are summarized in Table 1 and Fig. 1. To the contrary, when insulin was administered in diabetic patients, whose fasting blood glucose ranged from 108 to $208 \mathrm{mg} / 100 \mathrm{ml}$, blood glucose fell gradually and plasma glucagon did not increase at all. Even in a patient with the lowest fasting blood glucose level, $108 \mathrm{mg} / 100$ $\mathrm{ml}$, blood glucose reached the nadir of $55 \mathrm{mg} / 100 \mathrm{ml} 45 \mathrm{~min}$ after the insulin injection but the level of plasma glucagon did not increase from the baseline of $0.61 \mathrm{ng} / \mathrm{ml}$ through $120 \mathrm{~min}$ after the insulin injection. These changes of the mean glucose and plasma glucagon in six diabetic patients are presented in Table 2.

TABLE 1. Effect of insulin-induced hypoglycemix upon plasma glucagon in six normal subjects

\begin{tabular}{c|c|c}
\hline $\begin{array}{c}\text { Time after insulin } \\
\text { injection (min) }\end{array}$ & $\begin{array}{c}\text { Blood glucose } \\
(\mathrm{mg} / 100 \mathrm{ml})\end{array}$ & $\begin{array}{c}\text { Plasma glucagon } \\
\text { (ng/ml) }\end{array}$ \\
\hline & Mean $\pm \mathrm{sE}$ & Mean \pm sE \\
0 & $86.0 \pm 1.5$ & $0.18 \pm 0.06$ \\
15 & $40.8 \pm 2.0$ & $0.23 \pm 0.07$ \\
30 & $43.5 \pm 2.7$ & $0.84 \pm 0.14^{\dagger}$ \\
45 & $57.7 \pm 1.8$ & $1.18 \pm 0.40^{*}$ \\
60 & $61.3 \pm 2.3$ & $0.48 \pm 0.17^{*}$ \\
90 & $76.2 \pm 3.3$ & $0.37 \pm 0.11^{*}$ \\
120 & $83.7 \pm 1.9$ & $0.29 \pm 0.09$
\end{tabular}

Asterisks show significant differences compared with fasting level:

$* \mathrm{p}<.05, \dagger \mathrm{p}<.025$

Cataglycemia: As previously reported by one of the authors (Ohneda et al. 1969), when glucose infusion was discontinued and blood glucose fell rapidly, the levels of pancreatic glucagon increased in dogs. To see the effect of cataglycemia upon glucagon response in man, glucose infusion was stopped $60 \mathrm{~min}$ after the start of the infusion. After the withdrawal of glucose infusion, blood was obtained at a 15-minute interval for $45 \mathrm{~min}$. The changes in blood glucose, plasma glucagon and plasma insulin were presented in Table 3. The mean value of blood glucose was $78.5 \pm 1.9 \mathrm{mg} / 100 \mathrm{ml}$ at fasting and reached a plateau of $173.4 \pm 13.6 \mathrm{mg} / 100$ $\mathrm{ml} 45 \mathrm{~min}$ after the infusion of glucose. The mean level of blood glucose just prior to the discontinuance of glucose was $165.0 \pm 12.9 \mathrm{mg} / 100 \mathrm{ml}$ and this fell suddenly, reaching $101.9 \pm 8.3$ and $68.8 \pm 3.6 \mathrm{mg} / 100 \mathrm{ml} 15$ and $30 \mathrm{~min}$ after the withdrawal of glucose, respectively. The level of plasma glucagon, which was 


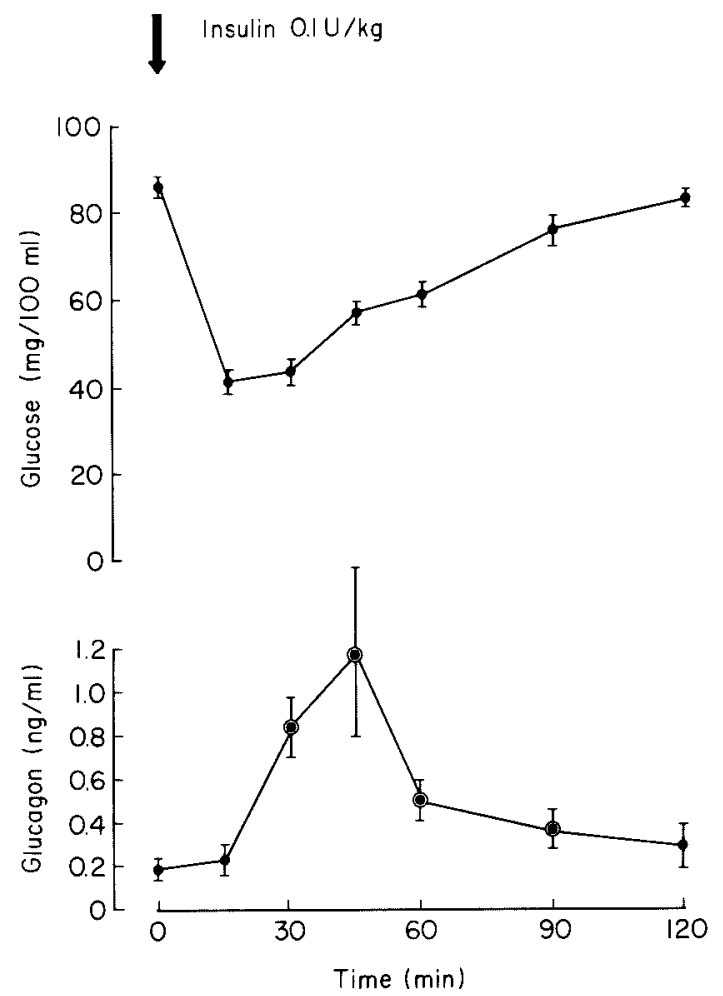

Fig. 1. Effect of insulin-induced hypoglycemia upon plasma glucagon response in normal subjects. Each double circle on the mean curve of glucagon indicates that the value differs significantly from the baseline at zero time $(p<.05)$

TABLE 2. Effect of insulin injection on plasma glucagon in six diabetic subjects

\begin{tabular}{c|c|c}
\hline $\begin{array}{c}\text { Time after insulin } \\
\text { injection (min) }\end{array}$ & $\begin{array}{c}\text { Blood glucose } \\
(\mathrm{mg} / \mathrm{l} 00 \mathrm{ml})\end{array}$ & $\begin{array}{c}\text { Plasma glucagon } \\
(\mathrm{ng} / \mathrm{ml})\end{array}$ \\
\hline & Mean $\pm \mathrm{SE}$ & Mean $\pm \mathrm{SE}$ \\
0 & $153.8 \pm 16.9$ & $0.41 \pm 0.06$ \\
30 & $126.0 \pm 9.4$ & \\
45 & $94.3 \pm 8.4$ & $0.40 \pm 0.07$ \\
60 & $80.0 \pm 11.6$ & \\
90 & $73.3 \pm 17.4$ & $0.36 \pm 0.05$ \\
120 & $99.2 \pm 12.9$ & $0.37 \pm 0.07$ \\
& $109.7 \pm 12.8$ & $0.38 \pm 0.06$
\end{tabular}

suppressed slightly by hyperglycemia, did not show any significant rise from the level prior to the withdrawal of glucose, $0.27 \pm 0.06 \mathrm{ng} / \mathrm{ml}$ during a rapid fall of blood glucose. Elevated plasma insulin during glucose infusion was lowered by cataglycemia and remained at low level for $45 \mathrm{~min}$.

Tetragastrin, secretin and pancreozymin: Blood specimens were taken before and $1,3,6,10,15,20,30,45$ and $60 \mathrm{~min}$ after the intravenous injection of one of these hormones. The changes in blood glucose, plasma glucagon and plasma 
TABLE 3. Effect of cataglycemia upon blood glucose, plasma glucagon and plasma insulin in eight normal subjects

\begin{tabular}{|c|c|c|c|c|}
\hline \multicolumn{2}{|c|}{$\begin{array}{l}\text { Time after glucose } \\
\text { administration (min) }\end{array}$} & $\begin{array}{c}\text { Glucose } \\
(\mathrm{mg} / 100 \mathrm{ml})\end{array}$ & $\begin{array}{l}\text { Glucagon } \\
(\mathrm{ng} / \mathrm{ml})\end{array}$ & $\begin{array}{c}\text { Insulin } \\
(\mu \mathrm{U} / \mathrm{ml})\end{array}$ \\
\hline \multirow{5}{*}{ 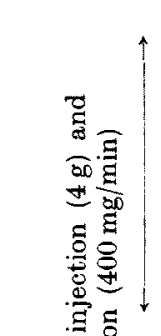 } & 0 & $\begin{array}{c}\text { Mean } \pm \text { SE } \\
78.5 \pm 1.9\end{array}$ & $\begin{array}{c}\text { Mean } \pm S E \\
0.29 \pm 0.07\end{array}$ & $\begin{array}{r}\text { Mean } \pm \text { SE } \\
24.5 \pm 3.1\end{array}$ \\
\hline & 15 & $150.8 \pm 7.7$ & $0.27 \pm 0.06$ & 46. $6 \pm 4.2$ \\
\hline & 30 & $159.0 \pm 10.4$ & $0.30 \pm 0.07$ & 50. $3 \pm 4.3$ \\
\hline & 45 & $173.4 \pm 13.6$ & $0.20 \pm 0.03$ & $60.1 \pm 11.3$ \\
\hline & 60 & $165.0 \pm 12.9$ & $0.27 \pm 0.06$ & $68.6 \pm 17.8$ \\
\hline \multirow{3}{*}{ 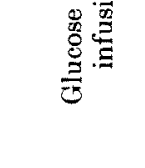 } & 75 & $101.9 \pm 8.3$ & $0.23 \pm 0.05$ & $49.5 \pm 9.3$ \\
\hline & 90 & $68.8 \pm 3.6$ & $0.28 \pm 0.07$ & $31.3 \pm 4.7$ \\
\hline & 105 & $57.5 \pm 1.6$ & $0.22 \pm 0.04$ & $28.5 \pm 3.0$ \\
\hline
\end{tabular}

insulin were presented in Table 4 . The mean glucose level did not fluctuate after the administration of either hormone. The mean level of plasma glucagon did not change at all after the injection of gastrointestinal hormones. A significant rise in plasma insulin was observed only 3 and 6 min after the injection of secretin. Whereas the injection of tetragastrin produced a slight increase in plasma insulin, though not significant, pancreozymin did not induce any changes in the level of plasma insulin.

L-Arginine: The infusion of L-arginine was carried out following the experiment with cataglycemia in eight normal subjects. Blood samples were obtained before and after the administration of L-arginine at 15-minute intervals for $75 \mathrm{~min}$. The changes in blood glucose, plasma glucagon and plasma insulin in normal subjects were summarized in Table 5 and Fig. 2. The mean level of blood glucose rose gradually and reached the peak $30 \mathrm{~min}$ after the infusion of L-arginine. The mean level of blood glucose fell to the initial level by $90 \mathrm{~min}$ after the start of the infusion of L-arginine. The mean level of blood glucose fell to the initial level by $90 \mathrm{~min}$ after the start of L-arginine infusion. The mean level of plasma glucagon was $0.22 \pm 0.04 \mathrm{ng} / \mathrm{ml}$ before the infusion and rose to a peak of $0.52 \pm$ $0.08 \mathrm{ng} / \mathrm{ml} 30 \mathrm{~min}$ after the administration of L-arginine. The elevated plasma glucagon remained significantly increased over the initial level through the experiment $(\mathrm{p}<.025)$. The mean value of plasma insulin rose to a peak of $44.8 \pm 6.8$ $\mu \mathrm{U} / \mathrm{ml}$ from the initial level of $28.5 \pm 3.0 \mu \mathrm{U} / \mathrm{ml}$, returning to the fasting level 45 min after the withdrawal of L-arginine infusion. The changes in blood glucose and plasma glucagon after the infusion of L-arginine in four diabetic patients were presented in Table 6. In this experiment blood samples were obtained at 10 minute intervals for $60 \mathrm{~min}$ and later at 15 -minute intervals. Blood glucose went up to a peak level of $117.5 \pm 8.9 \mathrm{mg} / 100 \mathrm{ml}$ from the fasting level of $85.0 \pm 7.0 \mathrm{mg} /$ $100 \mathrm{ml}$ and the return to the initial level delayed. Plasma glucagon rose from 


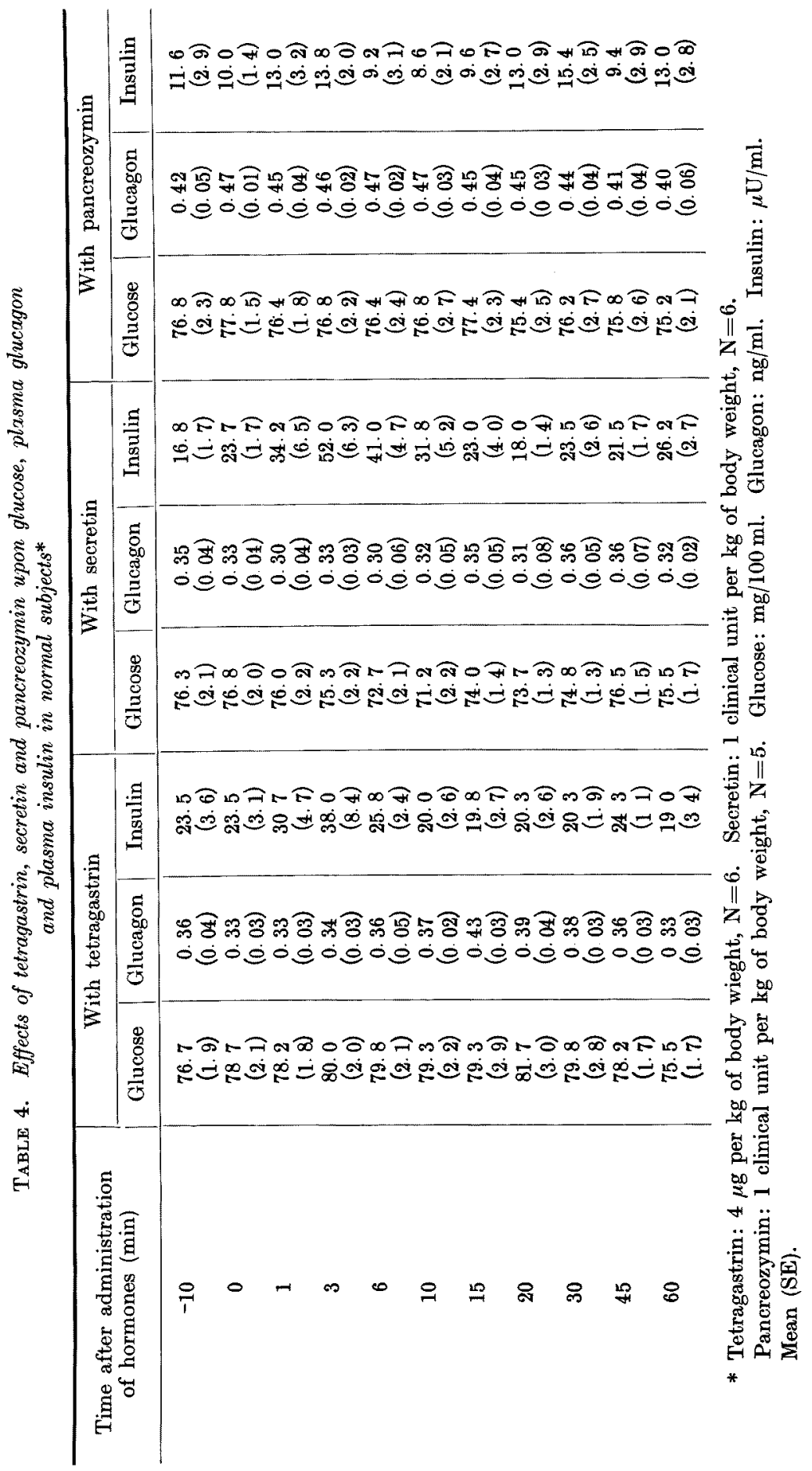


TABLE 5. Effect of L-arginine upon blood glucose, plasma glucagon and plasma insulin in eight normal subjects

\begin{tabular}{|c|c|c|c|c|}
\hline \multicolumn{2}{|c|}{$\begin{array}{l}\text { Time after L-arginine } \\
\text { infusion (min) }\end{array}$} & $\begin{array}{c}\text { Glucose } \\
(\mathrm{mg} / 100 \mathrm{ml})\end{array}$ & $\begin{array}{l}\text { Glucagon } \\
(\mathrm{ng} / \mathrm{ml})\end{array}$ & $\begin{array}{l}\text { Insulin } \\
(\mu \mathrm{U} / \mathrm{ml})\end{array}$ \\
\hline \multicolumn{2}{|c|}{ Fasting+ } & $\begin{array}{r}\text { Mean } \pm \mathrm{SE} \\
75.8 \pm 1.9\end{array}$ & $\begin{array}{c}\text { Mean } \pm S E \\
0.29 \pm 0.07\end{array}$ & $\begin{array}{r}\text { Mean } \pm \mathrm{SE} \\
24.5 \pm 3.1\end{array}$ \\
\hline \multirow{5}{*}{ 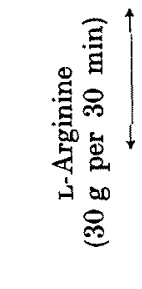 } & 0 & $57.5 \pm 1.6$ & $0.22 \pm 0.04$ & $28.5 \pm 3.0$ \\
\hline & 15 & $63.4 \pm 2.7 \S$ & $0.36 \pm 0.05^{*}$ & $44.8 \pm 6.8^{*}$ \\
\hline & 30 & $75.9 \pm 2.6 \S$ & $0.52 \pm 0.08 \Im$ & 41. $1 \pm 4.37$ \\
\hline & 45 & $71.5 \pm 2.4 \S$ & $0.49 \pm 0.09 \dagger$ & $36.3 \pm 4.4^{*}$ \\
\hline & 75 & $61.9 \pm 2.7$ & $0.42 \pm 0.09 \ddagger$ & $24.8 \pm 3.4$ \\
\hline
\end{tabular}

+ Fasting levels show the value before the experiment with cataglycemia, which was followed by the experiment with $\mathrm{L}$-arginine.

Asterisks show significant difference compared with $\mathrm{O}$-value:

$$
* \mathrm{p}<.025 \dagger \mathrm{p}<.01 \ddagger \mathrm{p}<.005 \S \mathrm{p}<.001
$$

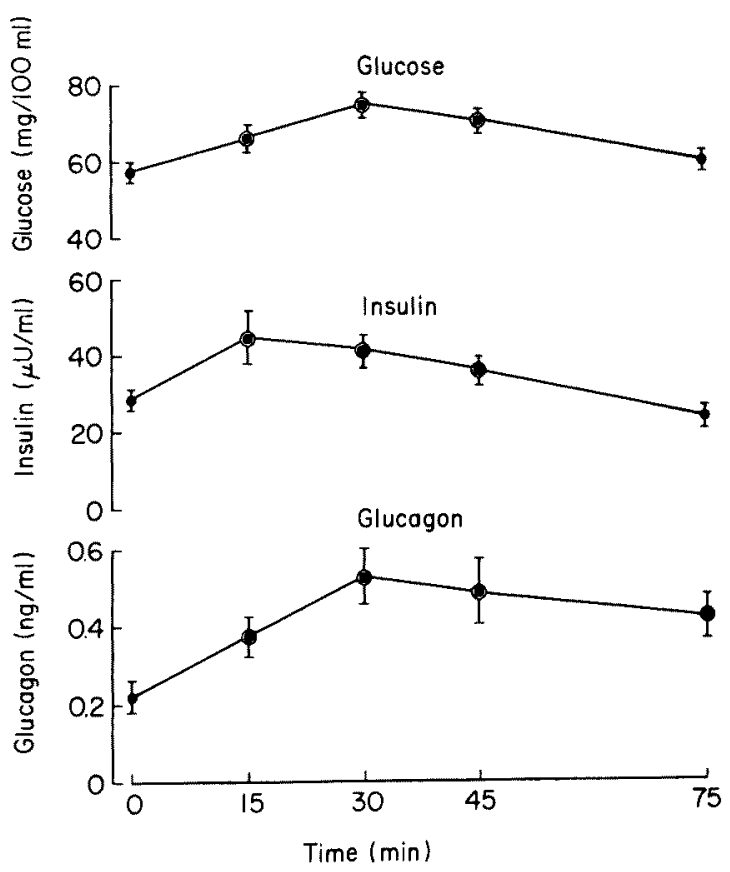

Fig. 2. Effect of L-arginine infusion upon blood glucose, plasma insulin and plasma glucagon in normal subjects. Each double circle indicates that the value differs significantly from the control value at zero time $(p<.025)$

the fasting level of $0.68 \pm 0.32 \mathrm{ng} / \mathrm{ml}$ after the infusion and reached a peak level of $2.28 \pm 0.72 \mathrm{ng} / \mathrm{ml}$ just prior to the completion of the infusion. The plasma glucagon remained elevated through the experiment. In this experiment the 
TABLE 6. Effect of L-arginine upon blood glucose and plasma glucagon in four diabetic patients.

\begin{tabular}{c|c|c}
\hline $\begin{array}{c}\text { Time after L-arginine } \\
\text { infusion (min) }\end{array}$ & $\begin{array}{c}\text { Glucose } \\
(\mathrm{mg} / 100 \mathrm{ml})\end{array}$ & $\begin{array}{c}\text { Glucagon } \\
\text { (ng/ml) }\end{array}$ \\
\hline & Mean $\pm \mathrm{sE}$ & Mean $\pm \mathrm{sE}$ \\
0 & $85.0 \pm 7.0$ & $0.68 \pm 0.32$ \\
10 & $97.5 \pm 7.5$ & $0.94 \pm 0.24$ \\
20 & $106.0 \pm 7.7$ & $1.53 \pm 0.60$ \\
30 & $113.5 \pm 8.8$ & $\mathbf{2 . 2 8 \pm 0 . 7 2}$ \\
40 & $117.5 \pm 8.9$ & $2.11 \pm 0.57$ \\
50 & $117.0 \pm 9.4$ & $2.21 \pm 0.77$ \\
60 & $113.5 \pm 9.1$ & $1.15 \pm 0.24$ \\
75 & $105.5 \pm 9.2$ & $0.82 \pm 0.26$ \\
90 & $96.8 \pm 8.4$ & $1.16 \pm 0.33$
\end{tabular}

insulin level in plasma was not measured because the diabetic patients had been treated with insulin.

\section{Discussion}

The increase in plasma glucagon was demonstrated in the experiment with insulin-induced hypoglycemia and L-arginine among the various stimuli which have been shown to induce pancreatic glucagon secretion in animals. From the standpoint of hyperglycemic action of glucagon, it is reasonable that hypoglycemic states induced glucagon secretion, which was well demonstrated in experimental animals. The response of plasma glucagon to insulin-induced hypoglycemia was observed in normal subjects but not in diabetic patients. The difference between the responses of plasma glucagon to hypoglycemia in normal and diabetic subjects may be derived from a grade and duration of hypoglycemia induced by insulin injection. Blood glucose fell to lower level in normal subjects than in diabetic patients. This result suggests that insulin injection in such dosis as 0.1 $\mathrm{U}$ per $\mathrm{kg}$ of body weight does not induce glucagon response in diabetic patients. Therefore, to see if pancreatic glucagon in diabetics responds to insulin hypoglycemia, the amount of insulin injected should be increased.

To the contrast, the rise in plasma glucagon was observed after L-arginine infusion in both normal and diabetic subjects. It was previously reported by Ohneda et al. $(1967,1968 \mathrm{a})$ that the intravenous administration of a mixture of amino acids stimulates the seeretion of pancreatic glucagon in dogs. The same effect of amino acids upon glucagon secretion was reported in man by Fajans et al. (1967). Although the effect of the individual amino acids upon the secretion of pancreatic glucagon has not been fully compared, recently L-arginine, a stimulant for growth hormone secretion, has been demonstrated to produce glucagon secretion in man (Assan et al. 1967, Aguilar-Parada et al. 1969, Dupre et al. 1969 and Samols et al. 1969). The results of the present study demonstrated that the infusion of L-arginine produced as great response of plasma glucagon as did the hypoglycemia induced by insulin, and suggest that L-arginine infusion is much 
more useful in the diagnosis of hypoglycemia due to glucagon deficiency than the insulin injection.

According to the results obtained in animal experiments, pancreozymin is a potent stimulant for the secretion of both insulin and pancreatic glucagon (Unger et al. 1967). To the contrary, no increase in plasma insulin or glucagon was observed after the injection of pancreozymin in our experiment. One of the possible reasons for the failure to stimulate the secretion of insulin or glucagon by pancreozymin may be that a smaller dosis (one clinical unit per kg of body weight) was employed in the present experiment as compared with the amounts used in animal experiments in which 100 Crick units and 600 units of the hormone were administered (Unger et al. 1967) by injection and infusion, respectively. The amount of the hormone used in the study was the same dosis as used in the practical pancreozymin test for the exocrine function of the pancreas in which an increased output of bile and pancreatic enzymes has been observed. In another experiment, however, 100 clinical units of pancreozymin injected into the celiac artery in man did not cause any rise in circulating plasma insulin or glucagon (unpublished observation). Furthermore, the dose given to normal subjects cauced slight sideeffects; nausea or abdominal pain, therefore, the dose could not be increased much more. Although it was reported by Ohneda et al. (1968 b) and by Dupre et al. (1969) that 300 Crick units of pancreozymin administered intravenously caused a rise in plasma glucagon in man, the administration of such a large amount of the hormone was obliged to give up in human subjects because of side-effects. Another possibility to account for the failure to induce glucagon secretion in man is that the mode of response to pancreozymin, by which the hormone stimulates glucagon secretion, may differ depending on species.

It is well known that secretin stimulates the secretion of insulin in animals as well as in man. According to Unger et al. (1967), glucagon in the pancreaticoduodenal vein did not rise after the injection of secretin in dogs. The plasma level of insulin in the peripheral vein was elevated by secretin injectin in the study but no change in the plasma glucagon level was observed. Although a suppression of glucagon secretion by secretin was recently reported by Santeusanio et al., (1971)., the present study did not confirm their results.

The failure to increase plasma glucagon by gastrin in dogs was reported by Unger et al. (1967), whereas the stimulation of the secretion of pancreatic glucagon by the gastrin tetrapeptide was demonstrated by Kaneto et al. (1970). In the present study, however, we could not observe a significant rise in glucagon level in the peripheral vein in man following the injection of gastrin tetrapeptide. According to Kaneto et al. (1970), an increase in plasma glucagon was found only in the pancreaticoduodenal vein and not in the femoral artery. The results obtained in the present study do not exclude the possibility that gastrin also stimulates glucagon secretion, since the changes in the level of plasma glucagon in the peripheral vein were found to be abolished by systemic circulation.

As reported previously by Ohneda and Yamagata (1971), the most important 
factor which influences the plasma glucagon level measured by radioimmunoassay is the immunological character of the anti-glucagon serum used, because the main component of circulating glucagon-like immunoreactivity in fasting is derived from the gut (Eisentraut et al. 1968, Heding 1971). Recently, pancreatic glucagon in human plasma has been determined by the radioimmunoassay using the antiglucagon sera which react with only pancreatic glucagon but not gut glucagonlike immunoreactive substance (Eisentraut et al. 1968, Samols et al. 1969, Heding 1971). According to Unger et al. (1970), the fasting glucagon level in man is 108 $\pm 10 \mathrm{pg} / \mathrm{ml}$ which is the lowest value among those hitherto reported. The antiglucagon serum, $30 \mathrm{~K}$, used in the present experiment, is specific for pancreatic glucagon, although it does still weakly cross-react with glucagon-like immunoreactive substance of the gut. In our experiment, the fasting glucagon level in normal subjects ranged from 0.05 to $0.51 \mathrm{ng} / \mathrm{ml}$, which is slightly higher than the value reported by Unger et al. (1970).

Recently Unger and co-workers (1970) have demonstrated the hyperresponsiveness of glucagon to arginine in diabetes mellitus and suggested that alpha cell function of the pancreas is inappropriately increased in diabetics. In our experiment, the fasting plasma glucagon level in diabetic patients is slightly elevated in comparison with normal subjects $(\mathrm{p}<.025)$. The plasma glucagon levels were markedly elevated after arginine infusion and these results consist with the conclusion of Unger et al. (1970). In order to obtain the conclusive evidence, however, it is necessary to investigate the plasma glucagon response in a large number of and various types of diabetic patients.

\section{Acknowledgments}

We are indebted to Dr. R.H. Unger, University of Texas, Southwestern Medical School, Dallas, Texas, for his generosity in supplying us with anti-glucagon serum and to Mrs. Mary Root, Ph.D., The Lilly Research Laboratory, Indianapolis, Indiana, for the supply of crystalline glucagon. This study was supported in part by a grant from the B yotai Taisha Foundation, Tokyo.

\section{References}

1) Assan, R., Rosselin, G. \& Dolais, J. (1967) Effets sur la glucagonémie des perfusions et ingestions d'acides amines. Journées Annuelles Diabétologie de Hôtel-Dieu, 7, 2541.

2) Aguilar-Parada, E., Eisentaut, A.M. \& Unger, R.H. (1969) Effects of starvation on plasma pancreatic glucagon in normal man. Diabetes, 18, 717-723.

3) Dupre, J., Curtis, J., Unger, R.H., Waddell, R.W. \& Beck, J.C. (1969) Effects of secretin, pancreozymin, or gastrin on the response of the endocrine pancreas to administration of glucose or arginine in man. $J$. clin. Invest., 48, 745-757.

4) Edwards, J.C., Howell, S.L. \& Taylor, K.W. (1969) Fatty acids as regulators of glucagon secretion. Nature, 224, 808-809.

5) Eisentraut, A.M., Ohneda, A., Parada, E. \& Unger, R.H. (1968) Immunologic discrimination between pancreatic and enteric glucagon-like immunoreactivity (GLI) in tissues and plasma. Diabetes, 17, 321-322.

6) Fajans, S.S., Floyd, J.C., Jr., Knopf, R.F. \& Conn, J.W. (1967) Effect of amino acids and proteins on insulin secretion in man. Recent Progr. Hormone Res., 23, 617-662.

7) Heding, L.G. (1971) Radioimmunological determination of pancreatic and gut gluca- 
gon in plasma. Diabetologix, 7, 10-19.

8) Herbert, V., Lau, K-S., Gottlieb, C.W. \& Bleicher, S.J. (1965) Caoated charcoal immunoassay of insulin. J. clin. Endocr., 25, 1375-1384.

9) Kaneto, A. \& Kosaka, K. (1970) Stimulation of glucagon secretion by oxytocin. Endocrinology, 87, 439-444.

10) Kaneto, A., Mizuno, Y., Tasaka, Y. \& Kosaka, K. (1970) Stimulation of glucagon secretion by tetragastrin. Endocrinology, 86, 1175-1180.

11) Lawrence, A.M. (1966) Radioimmunoassayable glucagon levels in man: Effects of starvation, hypoglycemia, and glucose administration. Proc. nat. Acad. Sci. U.S., 55, $316-320$.

12) Madison, L.L., Seyffert, W.A. Jr., Unger, R.H. \& Bosher, B. (1968) Effect of plasma free fatty acids on plasma glucagon and serum insuiin concentrations. Metabolism, 17, 301-304.

13) Morgan, C.R. \& Lazarow, A. (1962) Immunoassay of insulin using a two-antibody system. Proc. Soc. exp. Biol. Med., 110, 29-32.

14) Ohneda, A., Ketterer, H., Eisentraut, A.M. \& Unger, R.H. (1967) Effect of glucose and amino acids on glucagon. Clin. Res., 15, 62 .

15) Ohneda, A., Parada, E., Eisentraut, A.M. \& Unger, R.H. (1968a) Characterization of response of circulating glucagon to intraduodenal and intravenous administration of amino acids. J. clin. Invest., 47, 2305-2322.

16) Ohneda, A., Ketterer, H., Eisentraut, A.M. \& Unger, R.H. (1968b) Effects of gut hormone on insulin and glucagon secretion. Acta. diabet, lati, 5, 499-512.

17) Ohneda, A., Aguilar-Parada, E., Eisentraut, A.M. \& Unger, R.H. (1969) Control of pancreatic glucagon secretion by glucose. Diabetes, 18, 1-10.

18) Ohneda, A., Toyota, T., Sato, S. \& Yamagata, S. (1970) Extraction of plasma insulin in radioimmunoassay for removal of nonspecific inhibitor and of circulating insulin antibody. Tohoku J. exp. Med., 100, 75-84.

19) Ohenda, A. \& Yamagata, S. (1971) Evidence for the presence of inhibitor and some trials for its prevention in radioimmunoassay of plasma glucagon by two-antibody system. Tohoku J. exp. Med., 102, 247-268.

20) Ohneda, A. (1971) Radioimmunoassay for glucagon, Saishinigaku (Jap.), 26, 10971103.

21) Samols, E., Tyler, J. Marri, G. \& Marks, V. (1965) Stimulation of glucagon secretion by oral glucose. Lancet, 2, 1257-1259.

22) Samols, E., Tyler, J.M. \& Mialhe, P. (1969) Suppression of pancreatic glucagon release by the hypoglycaemic sulphonylureas. Lancet, 1, 174-176.

23) Santeusanio, F., Faloona, G.R. \& Unger, R.H. (1971) Glucagon-suppressing action of secretin. Diabetes, Supp. 1, 20, 339.

24) Teller, J.D. (1956) Direct, quantitative, colorimetric determination of serum or plasma glucose. Abstracts of papers, 130th Meeting, Amer. chem. Soc., p. 69C.

25) Unger, R.H., Eisentraut, A.M., McCall, M.S. \& Madison, L.L. (1962) Measurements of endogenous glucagon in plasma and the influence of blood glucose concentration upon its secretion. J. clin. Invest., 41, 682-689.

26) Unger, R.H., Ketterer, H., Dupré, J. \& Eisentraut, A.M. (1967) The effects of secretin, pancreozymin, and gastrin on insulin and glucagon secretion in anesthetized dogs. J. clin. Invest., 46, 630-645.

27) Unger, R.H., Ohneda, A., Valverde, I., Eisentraut, A.M. \& Exton, J. (1968) Characterization of the responses of circulating glucagon-like immunoreactivity to intraduodenal and intravenous administration of glucose. J. clin. Invest., 47, 48-65.

28) Unger, R.H., Ohneda, A., Aguilar-Parada, E. \& Eisentraut, A.M. (1969) The role of aminogenic glucagon secretion in blood glucose homeostasis. J. clin. Invest., 48, $810-822$.

29) Unger, R.H., Aguilar-Parada, E., Müller, W.A. \& Eisentraut, A.M. (1970) Studies of pancreatic alpha cell function in normal and diabetic subjects. J. clin. Invest., 49, 837-848. 